\title{
History and Turning the Antitrust Page
}

\author{
Brian R. Cheffins*
}

July 2021

\begin{abstract}
Present-day advocates of antitrust reform referred to as "New Brandeisians" have invoked history in pressing the case for change. The New Brandeisians bemoan the upending of a mid- $20^{\text {th }}$ century "golden age" of antitrust by an intellectual movement known as the Chicago School. In fact, mid- $20^{\text {th }}$ century enforcement of antitrust was uneven and large corporations exercised substantial market power. The Chicago School also was not as decisive an agent of change as the New Brandeisians suggest. Doubts about the efficacy of government regulation and concerns about foreign competition did much to foster the late $20^{\text {th }}$ century counter-revolution antitrust experienced.
\end{abstract}


Marc Levinson, in his review in this journal of Thomas Philippon's 2019 book, The Great Reversal, suggested engagement with "the very rich historical literature on competition and market power" would have improved an otherwise "fascinating book." The Great Reversal is part of "a torrent of recent studies"2 documenting a growing concentration of market share in key American industries, buttressed by rising markups and persistently high profits. ${ }^{3}$ Such evidence of the accumulation and exercise of market power has convinced many that with antitrust, a venerable form of business regulation which targets anticompetitive business practices, "a full turning of the page" is essential. ${ }^{4}$

While Philippon may not have drawn on history to the extent he could have done in The Great Reversal, current pleas for change on the antitrust front have a strong historical undercurrent. The most enthusiastic advocates of reform are known as "New Brandeisians," harkening back to a distinguished jurist, Louis Brandeis, who warned of "the curse of

\footnotetext{
$1 \quad$ Mark Levinson, "Book Review”, Business History Review 94 (2020): 453, 454, discussing Thomas Philippon, The Great Reversal (Cambridge, Mass., 2019).

2 Robert Harding, "How Buffett Broke American Capitalism," Financial Times, 13 September 2017, 11.
}

3 See, for example, "Benefits of Competition and Indicators of Market Power," Council of Economic Advisers Issue Brief, Spring 2016; Matias Covarrubias, German Gutierrez and Thomas Philippon, "From Good to Bad Concentration? U.S. Industries over the Past 30 Years," NBER Macroeconomics Annual 34 (2019): 1; Gustavo Grullon, Yelena Larkin and Roni Michaely, "Are U.S. Industries Becoming More Concentrated?," Review of Finance 23 (2019): 697; Jan De Loecker, Jan Eeckhout and Gabriel Unger, "The Rise of Market Power and the Macroeconomic Implications," Quarterly Journal of Economics 135 (2020): 561.

$4 \quad$ James Politi and Lauren Fedor, "The New Antitrust Chief Taking on Big Tech," Financial Times, 19 June 2021, 11.

5 Michael Tennant, "Monopolies: Fears, Facts and Fallacies," New American, 5 March 2018, 10, 11; Seth B. Sacher \& John M. Yun, "Twelve Fallacies of the Neo-Antitrust Movement," George Mason Law Review 26 (2019): 1491, 1493. For an overview of the schools of thought regarding antitrust reform, see Roger Parloff, "Behind the Big Tech Antitrust Backlash: A Turning Point for America," Yahoo! Finance, 11 December 2019, https://uk.finance.yahoo.com/news/amazon-facebook-google-antitrust-backlash152518336.html. 
bigness" more than a century ago. ${ }^{6}$ The New Brandeisians, consistent with their backwardlooking moniker, have invoked history with some regularity in making their arguments for present-day reform. ${ }^{7}$ For instance, Lina Khan, a leading figure in the New Brandeisian movement, ${ }^{8}$ praised mid-20 ${ }^{\text {th }}$ century America antitrust in a widely cited 2017 Yale Law Journal article on the basis enforcement was shaped by "recognition that excessive concentrations of private power posed a public threat, empowering the interests of a few to steer collective outcomes." 9

The occurrence of meaningful antitrust changes cannot be taken for granted, given the possibility of substantial inertia in Congress and the courts. ${ }^{10}$ The New Brandeisians nevertheless have the wind in their sails, and history is helping to set the antitrust reform tone. When Khan was appointed chair of the Federal Trade Commission (FTC) in 2021, law professor David Singh Grewal said "What she's doing is really just returning antitrust and market policy to the status quo ante, of the 20 s through the $60 \mathrm{~s}$, even the $70 \mathrm{~s} . " 11$ Numerous antitrust-related bills have been proposed in Congress recently, ${ }^{12}$ and the proponent of one of these, Senator Amy Klobuchar, ${ }^{13}$ fortified her case for reform with a 624-page book on

\footnotetext{
6 Louis D. Brandeis, “A Curse of Bigness,” Harper's Weekly, 10 January 1914, 18. 7 Tennant, "Monopolies," 11.

$8 \quad$ Eric Posner, “Biden's Antitrust Revolutionaries," Project Syndicate, 18 June 2021, https://www.project-syndicate.org/commentary/new-brandeisians-antitrust-for-big-tech-byeric-posner-2021-06

9 Lina M. Khan, “Amazon's Antitrust Paradox,” Yale Law Journal 126 (2017): 710,
} 742.

10 Richard Waters, "Biden's New Trustbuster Faces a Battle to Rein in Big Tech," Financial Times, 18 June 2021, 9; "Khan Brings a Chance to Reshape Antitrust Policy," Financial Times, 23 June 2021, 22.

11 James Politi and Lauren Fedor, "The New Antitrust Chief Taking on Big Tech," Financial Times, 19 June 2021, 11.

12 “Is Facebook a Monopolist?," Economist, 3 July 2021, 65.

13 "Senator Klobuchar Introduces Sweeping Bill to Promote Competition and Improve Antitrust Enforcement," 4 February 2021, 
antitrust where a majority of the chapters focused on history. ${ }^{14}$ President Joe Biden has likewise invoked history to make the case in favor of antitrust changes. When signing a July 2021 executive order encouraging federal agencies to promote competitive markets he said "Forty years ago, we chose the wrong path, in my view, following the misguided philosophy of people like Robert Bork, and pulled back on enforcing laws to promote competition." 15

President Biden, in invoking Bork, referenced what is for the New Brandeisians the key phase of antitrust history. The New Brandeisian narrative revolves around the Chicago School, a market-friendly intellectual movement associated with the University of Chicago, corrupting an American anti-monopoly tradition as the $20^{\text {th }}$ century drew to a close. ${ }^{16}$ Bork, a Yale academic, U.S. solicitor-general and federal court of appeals judge, was a University of Chicago law school graduate and the "most combative evangelist" of Chicago-style antitrust thinking. ${ }^{17}$

As this essay shows, the historical analysis the New Brandeisians have been relying upon in their influential push for antitrust reform is problematic. The New Brandeisian version of events presumes that there was a mid- $20^{\text {th }}$ century golden age of antitrust that implementation of Chicago School theorizing upended. Such nostalgia is misplaced. During the middle decades of the $20^{\text {th }}$ century, large corporations were exercising substantial market

https://www.klobuchar.senate.gov/public/index.cfm/2021/2/senator-klobuchar-introducessweeping-bill-to-promote-competition-and-improve-antitrust-enforcement .

14 Amy Klobuchar, Antitrust: Taking on Monopoly Power from the Gilded Age to the Digital Age (New York, 2021).

15 White House, "Remarks by President Biden At Signing of An Executive Order Promoting Competition in the American Economy," 9 July 2021.

16 William E. Kovacic, "The Chicago Obsession in the Interpretation of U.S. Antitrust History," University of Chicago Law Review 87 (2020): 459, 462-63; Daniel A. Crane, "The New Crisis in Antitrust (?)," Antitrust Law Journal 83 (2020): 253, 253-55, 268.

17 Parloff, "Behind the Big Tech"; Steven M. Teles, The Rise of the Conservatives Legal Movement (Princeton, N.J., 2008), 94. 
power amidst uneven antitrust enforcement. As for the Chicago School, it clearly was influential. Growing doubts about the efficacy of government regulation and the rise of foreign competition also contributed substantially, however, to the late $20^{\text {th }}$ century antitrust counter-revolution with which the Chicago School is associated. Hence, the New Brandeisian invocation of mid- and late- $20^{\text {th }}$ century history to support the turning of the antitrust page is dubious in key respects.

\section{New Brandeisian Antitrust History}

President Biden said when signing the July 2021 executive order relating to the promotion of competition "what we've seen over the past few decades is less competition and more concentration that holds our economy back." 18 This assessment accords with the New Brandeisians' pessimistic characterization of current market conditions in the United States. Senator Elizabeth Warren proclaimed in a high-profile 2016 speech "competition is dying". 19 Noted economist Joseph Stiglitz subsequently concurred, saying "we live in an economy where a few firms can get for themselves massive amounts of profits and persist in their dominant position for years and years." 20 In sum, "monopoly is back." 21

Warren, in condemning present-day arrangements, referred nostalgically to an era when "(a)ntitrust law was real—and American corporations knew it." 22 This era began, according to Warren, with a dramatic escalation of antitrust enforcement by the Department

18 White House, "Remarks".

19 Elizabeth Warren, "Reigniting Competition in the American Economy," Keynote Remarks at New America's Open Markets Program Event, 29 June 2016.

20 Joseph E. Stiglitz, “America Has a Monopoly Problem - and It's Huge," The Nation, 23 October 2017.

21 Stacy Mitchell, "The Rise and Fall of the Word 'Monopoly' in American Life," Atlantic.com, 20 June 2017, https://www.theatlantic.com/business/archive/2017/06/wordmonopoly-antitrust/530169/ .

22 Warren, "Reigniting". 
of Justice between 1938 and 1943 under the leadership of Thurman Arnold, the Assistant Attorney General in charge of the Department's Antitrust Division. ${ }^{23}$ Matt Stoller concurs in his 2019 book Goliath, saying after describing the entrenchment of Arnold's antitrust ethos during the 1950s and 1960s, "There was more competition, and increasing competition, in the economy at large". ${ }^{24}$ The mid- $20^{\text {th }}$ century thus was for New Brandeisians "a golden age of antitrust enforcement in which the U.S. government's expert regulators had the wisdom" to address "unfair, anticompetitive practices that harmed not just consumers but society as well." 25 Market power in turn did not have the baleful influence it has currently.

According to the New Brandeisians, disaster was around the corner, with a radical antitrust philosophy with strong roots in the University of Chicago corrupting the mid- $20^{\text {th }}$ century version of antitrust. ${ }^{26}$ Led by Robert Bork, the Chicago School declared "their intent to overthrow our antitrust laws," 27 arguing antitrust enforcers should forsake trying to protect competitors losing out to dominant rivals and attempting to safeguard democracy from concentrated private power. The focus should instead be on the closely related goals of enhancing consumer welfare and increasing economic efficiency. ${ }^{28}$

23 On how antitrust enforcement changed under Arnold, see Brian Cheffins, "The Development of Competition Policy, 1890-1940: A Re-Evaluation of a Canadian and American Tradition," Osgoode Hall Law Journal, 27 (1989): 449, 481-82.

24 Matt Stoller, Goliath (New York, 2019), 187-88. See also Tim Wu, The Curse of Bigness: Antitrust in the New Gilded Age (New York, 2018), 81-82.

25 Tennant, "Monopolies," 11; see also Klobuchar, Antitrust, 239.

26 David Dayen, “This Budding Movement Wants to Smash Monopolies," The Nation, 4 April 2017; Jonathan Tepper \& Denise Hearn, The Myth of Capitalism: Monopolies and the Death of Competition (Hoboken N.J., 2019), 155-58.

27 Barry C. Lynn, Cornered: The New Monopoly Capitalism and the Economics of Destruction (Hoboken, N.J.: 2009), 143.

28 Wu, Curse, 113-18; Dayen, "This Budding"; Lina M. Khan and Sandeep Vaheesan, "Market Power and Inequality: The Antitrust Counterrevolution and Its Discontents," Harvard Law \& Policy Review 11 (2017): 235, 268-69, 276. 
The New Brandeisians maintain that a Chicago-driven antitrust counter-revolution ${ }^{29}$ took place as the $20^{\text {th }}$ century drew to a close, prompting courts and regulators to default toward non-enforcement. ${ }^{30}$ And the New Brandeisians decry the adverse consequences -"(s)ince the implementation of antitrust deregulation, market power has widened." 31 Hence, a battle of ideas went badly awry, resulting in a "Bork led an intellectual revolution that sacrificed citizens at the altar of efficiency and cheap goods." ${ }^{32}$

In terms of chronology, the Supreme Court explicitly invoked Chicago School commentary in Continental Television v. GTE Sylvania in $1977 .{ }^{33}$ Then, in the 1980s, the market-friendly administration of Ronald Reagan drew heavily on Chicago School reasoning while revamping federal antitrust policy. ${ }^{34}$ Monopoly power, according to the New Brandeisians, duly thrived. ${ }^{35}$ As Lina Khan has said, "The result of this counterrevolution in antitrust, originating as an intellectual movement led by the Chicago School, stamped into policy by the Reagan administration, is that markets across sectors are highly concentrated." 36 Or as Warren argued in her 2016 speech, "the Bork approach to antitrust law...let companies

29 On the terminology, see Khan and Vaheesan, "Market Power", 275; Michael Isikoff and Merrill Brown, "Baxter's Reign: Evolution, Not Revolution," Washington Post, 11 December 1983, F1.

30 Khan, "Amazon's Antitrust", 727; Ariel Katz, "The Chicago School and the Forgotten Political Dimension of Antitrust Law," University of Chicago Law Review 87 (2020): 413, 414.

31 Jonathan B. Baker, The Antitrust Paradigm: Restoring a Competitive Economy (Cambridge, Mass., 2019), 2.

32 Tepper and Hearn, Myth of Capitalism, 158.

33 Continental Television v. GTE Sylvania, 433 U.S. 36, 48, 55-56 (1977).

34 Klobuchar, Antitrust, 136-37, 144-45, 148; Khan and Vaheesan, "Market Power", 294.

35 Tepper and Hearn, Myth of Capitalism, 158; Tim Wu, "The Utah Statement: Reviving Antimonopoly Traditions for the Era of Big Tech," OneZero, 18 November 2019; Thomas W. Hazlett, "The New Trustbusters Are Coming for Big Tech," Reason, October. 2019.

36 Khan and Vaheesan, "Market Power," 275. 
grow larger and larger." ${ }^{\text {"37 }}$ Eager to correct antitrust's ostensibly wayward turn, the New Brandiesians have been "rediscovering our traditions and updating them for the age in which we live today." 38

The New Brandeisians' invocation of history has gone largely unchallenged. The Chicago School, as they maintain, is widely thought of as providing the catalyst for the Reagan-era antitrust makeover that has been largely sustained through to the present day. ${ }^{39}$ This version of history merits, however, a closer, critical look, particularly given that New Brandeisian thinking is proving to be influential in current debates about antitrust reform. The mid- $20^{\text {th }}$ century's supposed golden age of antitrust is a prime candidate for re-evaluation with a turning of the antitrust page being in prospect.

How "Real" was Antitrust in the Mid-Twentieth Century?

Elizabeth Warren's suggestion that mid-20 2 th century antitrust was "real" might well be something of a surprise to those familiar with Richard Hofstadter's well-known 1964 essay "What Happened to the Antitrust Movement?"40 Hofstadter argued that due to "growing public acceptance of the large corporation," antitrust was "a faded passion" that had become "specialized, and bureaucratized." 41 How can this verdict be squared with Warren's? Essentially, there was meaningful mid-20 ${ }^{\text {th }}$ century antitrust enforcement, but within distinct

\footnotetext{
37 Warren, "Reigniting".
}

38 Stoller, Goliath, 453.

39 William E. Kovacic, "The Chicago Obsession in the Interpretation of US Antitrust History," University of Chicago Law Review 87 (2020): 459, 459-63,

$40 \quad$ Richard Hofstadter, "What Happened to the Antitrust Movement? Notes on the Evolution of an American Creed" in ed., Earl F. Cheit, The Business Establishment (New York, 1964), 113. 
limits. Large American corporations accordingly could accumulate and exercise substantial market power with substantial impunity.

The mid- $20^{\text {th }}$ century may well have been "antitrust's most interventionist period." 42 Even Hofstadter acknowledged "There is hardly a major industry that has not seen a significant lawsuit or two and in most industries in which intervention might be thought desirable government intervention has had more than negligible effects." 43 Certainly, antitrust "received considerable attention from the business community." 44 The Christian Science Monitor was telling readers in 1958 "These are good years for corporation lawyers whose clients are distressed by antitrust jitters." ${ }^{\prime 4}$ A decade later law professor Thomas Kauper said "Businessmen now commonly talk about antitrust; internal compliance programs have been initiated and carried out." 46

Mid-20 $0^{\text {th }}$ century antitrust featured for interested parties eye-catching jurisprudence. During this era, the Supreme Court adopted in relation to a wide range of conduct antitrust law regulated inflexible "per se" rules where a court was to presume conclusively a type of conduct was unreasonable and therefore illegal. ${ }^{47}$ According to Kauper "the rulings...rested on concerns over the straits of small entrepreneurs" and were "more consistent with civil

42 Seth B. Sacher and John M. Yun, "Twelve Fallacies of the Neo-Antitrust Movement," George Mason Law Review 26 (2019): 1491, 1500.

43 Hofstadter, "What Happened", 150.

44 Jesse W. Markham, "The New Antitrust Policy and the Individual Business Firm," Law and Contemporary Problems 30 (1965): 607, 611.

45 Vartanig G. Vartan, “Antitrust Lawyers Hit Hard at Big Business,” Christian Science Monitor, 21 July 1958, 3.

$46 \quad$ Thomas E. Kauper, "The Warren Court and the Antitrust Laws: Of Economics, Populism, and Cynicism," Michigan Law Review 67 (1968): 325, 335.

47 Thomas E. Kauper, "The Report of the Attorney General's National Committee to Study the Antitrust Laws: A Retrospective," Michigan Law Review 100 (2002): 1867, 187273. On the nature of per se rules, see Northern Pacific Ry. v. United States, 356 U.S. 1, 5 (1958). 
rights thinking than economic analysis." 48 Whatever the precise ideological underpinnings, with antirust appeals to the Supreme Court there was "a common belief....the result is preordained. Defense lawyers expect to lose."49 With justification; when Earl Warren was chief justice of the U.S. Supreme Court (1953 to 1969) government litigators won virtually all of the antitrust cases the court heard. ${ }^{50}$ Justice Potter Stewart confirmed this via an "acid comment" ${ }^{\prime 51}$ in his dissent in a 1966 case, United States v. Von's Grocery Co., saying that in merger cases coming before the court " $(\mathrm{t})$ he sole consistency" he could find was that "the Government always wins." 52

The Warren Court merger jurisprudence seemingly supplied antitrusters with "the leverage to stop any and all horizontal mergers." ${ }^{53}$ As the New York Times observed after the Supreme Court handed down its Von's Grocery judgment, "These court opinions, if acted upon fully, would practically eliminate from the American business scene the horizontal merger." ${ }^{54}$ That potential would be at best partially fulfilled. Uneven enforcement of antitrust law meant the mid- $20^{\text {th }}$ century business community was "chafing more at the Supreme Court than at administrative trustbusters."

$\begin{array}{ll}48 & \text { Kauper, "Report," } 1873 . \\ 49 & \text { Kauper, "Warren Court," } 336 . \\ 50 & \text { Ibid.; Richard A Posner, "The Antitrust Decisions of the Burger Court," Antitrust Law }\end{array}$ Journal (1979) 47: 819, 820.

$51 \quad$ Milton Handler, "Twenty-Five Years of Antitrust (Twenty-Fifth Annual Antitrust Review)," Columbia Law Review 73 (1973): 415, 456.

$52 \quad$ United States v. Von's Grocery Co., 384 U.S. 270, 301 (1966).

53 Arthur Austin, "Antitrust Reaction to the Merger Wave: The Revolution vs. the Counterrevolution," North Carolina Law Review 66 (1988): 931, 936.

54 Eileen Shanahan, "Antitrust Chief With a Sophisticated View", New York Times, 29 June 1966, 61. See also “Antitrust Turns Tougher," Business Week, 12 September 1964, 98. 55 Roger Lane, "Mergers, U.S. Policy On Them in Transition," Washington Post, 13 September 1964, 2. 
Post-World War II antitrust enforcement got off to a slow start, partly due to the Truman administration slashing appropriations to the Department of Justice's Antitrust Division as part of an economy drive the Korean War prompted. ${ }^{56}$ One by-product was that the 1950 Celler-Kefauver Act, ${ }^{57}$ which fortified anti-merger provisions in the 1914 Clayton Act ${ }^{58}$ went unused under Truman. ${ }^{59}$ Matters changed when Eisenhower became president.

In the twilight of the Eisenhower presidency, the New York Herald Tribune suggested that under his administration "mammoth corporations have taken quite a battering" due to antitrust. ${ }^{60}$ How did this happen with a Republican president? The Economist explained why in 1960:

"A surprising aspect of the Eisenhower Administration from the very beginning has been its anti-trust policy. As the 'party of big business' the Republicans were expected to deal gently with monopoly and anti-competitive practices. The disappointment of businessmen at the way things have turned out has been manifest. The Anti-trust Division of the Justice Department -- the agency chiefly responsible for the enforcement of the anti-trust laws -- has been tougher and more aggressive than its immediate predecessors under a Democratic Administration. Even the congressional Democrats most concerned with anti-trust matters have found little to criticise."

56 Theodore P. Kovaleff, Business and Government During the Eisenhower Administration: A Study of the Antitrust Policy of the Antitrust Division of the Justice Department (Athens, 1980), 11.

$57 \quad 64$ Stat. 1125.

$58 \quad 38$ Stat. 730.

59 Theodore P. Kovaleff, "The Antitrust Record of the Eisenhower Administration," Antitrust Bulletin 21 (1976): 589, 602.

60 Donald I. Rogers, "What Course for Trustbusting?," New York Herald-Tribune, 21 October 1960, 29.

61 “Mergers on Trial,” Economist, 20 February 1960, 717. 
Under Eisenhower the primary emphasis with antitrust was on mergers, with the greatest contribution being energetic enforcement of the revised Clayton Act. ${ }^{62}$ Eisenhower trustbusters brought most of the cases where the Warren Court interpreted the legislation liberally. ${ }^{63}$

It initially appeared the Kennedy administration would sustain the antitrust momentum. The Wall Street Journal said in 1961 that "(s)urgeons of the Kennedy administration are sharpening their antitrust scalpels" and were itching "to swing into offensive action to assault more existing corporate structures." ${ }^{\text {"64 }}$ Ultimately, though, the Kennedy Antitrust Division favored pursuing price-fixing cases of doubtful economic significance in lieu of cracking down on large corporations reputedly exercising quasimonopoly power. ${ }^{65}$ Attorney General Robert Kennedy's close monitoring of the Antitrust Division, motivated by concerns his brother's administration was unfairly thought of as “antibusiness", underpinned the cautious approach. ${ }^{66}$

Little changed when Lyndon Johnson became president. The Wall Street Journal suggested in 1965 that it was impossible Johnson's “consensus brand of politics would welcome a spirited campaign to break up big business". ${ }^{67}$ This meant if Donald Turner, the Harvard academic just appointed head of the Antitrust Division, "grows bold and attempts to

62 Kovaleff, “Antitrust Record”, 602, 609; "Eisenhower's Antitrusters Have a Busy Four Years in Store," Business Week, 15 December 1956, 60.

$63 \quad$ Kovaleff, Business and Government, 158.

64 William Beecher, “Antimonopoly Attack,” Wall Street Journal, April 13, 1961, 1.

65 Drew Pearson, "Monopoly Crackdown Forgotten?," Washington Post, 16 December 1962, E7; Mark J. Green, The Closed Enterprise System: Ralph Nader's Study Group on Antitrust Enforcement (New York, 1972), 77.

66 Green, Closed Enterprise, 74; Marc Allen Eisner, Antitrust and the Triumph of Economics: Institutions, Expertise, and Policy Change (Chapel Hill, N.C., 1991), 124-25. 67 James Harwood, “Antitrust's Mr. Turner,” Wall Street Journal, 12 July 1965, 14. 
expand the antitrust range, he can expect a lasso from the White House.”68 By 1967, "traditional, crusading trustbusters" had concluded "Turner's brand of antitrust is namby pamby." 69 The Wall Street Journal was even referring to "gentle trustbusters", saying that despite the misgivings of "old-time Washington liberals, gray haired survivors of the New Deal era when trustbusting was in vogue and business bigness was all bad....antitrust enforcement is becoming an anachronism in this era of the Great Society." ${ }^{\prime 70}$

Johnson did set up a task force to study antitrust in December 1967. He declined, however, to release the task force's July 1968 report. ${ }^{71}$ The Wall Street Journal explained why in 1969 when the Nixon administration made the report public: "The recommendations apparently weren't to the liking of Johnson, whose Administration displayed little enthusiasm for vigorous enforcement of antitrust statutes and none for new antitrust laws." 72

Arguably, a by-product of the not-so-golden mid- $20^{\text {th }}$ century antitrust era was the prevalence of the sort of market power which the New Brandeisians attribute to the late $20^{\text {th }}$ century Chicago-influenced corruption of antitrust. George David Smith and Davis Dyer maintain in a 1996 essay on the history of the American corporation "During the 1950s and '60s, most leading U.S. industrials held their dominant positions in domestic markets without substantial price competition." ${ }^{.73}$ Historian Gabriel Winant agrees, saying "The postwar years

$68 \quad$ Ibid.

$69 \quad$ “Taking the Crusade Out of Antitrust,” Business Week, 20 May 1967, 59.

70 Louis M. Kohlmeier, “Gentle Trustbusters,” Wall Street Journal, 7 March 1967, 18.

71 Eileen Shanahan, “Trust-Law Shift Urged," New York Times, 22 May 1969, 1; White House Task Force on Anti-trust Policy, "Task Force Report on Anti-trust Policy." 91st Congressional Record, first Senate session, 27 May 1969, 13890.

72 "Sweeping Reform of Antitrust Laws Urged In Report That Was Submitted to Johnson," Wall Street Journal, 22 May 1969, 4.

73 George David Smith \& Davis Dyer, "The Rise and Transformation of the American Corporation" in ed. Carl Kaysen, The American Corporation Today (New York, 1996), 28, 51. 
of the 1950s and '60s were the age of 'monopoly capitalism,' as the Marxists then called it, or, less polemically, an era of 'administered prices'.,"74

Contemporaries tended to be similarly pessimistic about market conditions. In the early 1950s, Harvard economist Sumner Slichter suggested "the belief that competition is dying is probably accepted by a majority of economists."75 Humorist Art Buchwald speculated in a Washington Post column in 1966 that by 1978 all corporations west of the Mississippi River would have merged into a single corporation, that the same would have happened east of the Mississippi and that the two companies would soon be looking to merge so there would be only one corporation in the United States. ${ }^{76}$

Those responsible for administering and applying America's antitrust laws were far from sanguine themselves. Victor Hansen, head of the Antitrust Division from 1956 to 1959, said while in office "Economic concentration is increasing." 77 The Wall Street Journal reported in 1961 "trust-busters are convinced many industries set prices by follow-the-leader techniques." 78

Antitrust policy was thought to be at least partly to blame for the truncation of market forces. The antitrust task force Johnson struck and then ignored reported "Highly concentrated industries account for a large share of manufacturing activity in the United States" and, citing "a gap in the law," recommended legislation to break up "entrenched oligopolies" so as to "reduce concentration in industries where monopoly power is shared by

74 Gabriel Winant, "No Going Back: The Power and Limits of the Anti-Monopolist Tradition,” Nation.com, 21 January 2020.

75 John Bellamy Foster, Robert W. McChesney and R. Jamil Jonna, "Monopoly and Competition in Twenty-First Century Capitalism," Monthly Review, April 2011, 1, 19.

76 Art Buchwald, "Capitol Punishment...: Everyone Is Merging," Washington Post, 2 June 1966, 21.

77 James A. Reynolds, “Antitrust Hustle,” Wall Street Journal, 16 January 1957, 1.

78 William Beecher, “Antimonopoly Attack,” Wall Street Journal, 13 April 1961, 1. 
a few very large firms." ${ }^{" 79}$ Buchwald's punchline in the 1966 column where he speculated that 1978 America's two remaining corporations might merge made the point more whimsically. He suggested that trustbusters would "naturally study this merger to see if it violates our strong anti-trust laws" but would ultimately clear the merger, leaving the United States with just the one corporation. ${ }^{80}$

\section{Regulation Misgivings}

While antitrust was not the potent check on business activity during the mid-20 $0^{\text {th }}$ century that the New Brandeisian version of events imply, antitrust was by no means a spent force when the 1970s rolled around. The decade has been described as "a period of intense antitrust activity" 81 and "the heyday" of antitrust enforcement. ${ }^{82}$ For instance, Gerald Ford pledged as president "a return to the vigorous enforcement of antitrust law" 83 and the Antitrust Division's budget and staff levels increased markedly during his administration. ${ }^{84}$

Unlike with the Eisenhower/Kennedy transition, antitrust momentum was fully sustained when the Democrats took over the White House from the Republicans in the 1970s. Reputedly, “(a)ntitrust activity hit its stride during Jimmy Carter's presidency”, ${ }^{85}$ fulfilling a 1977 prediction by Forbes that the business community could "be in for a rough time on the

\footnotetext{
79 White House Task Force on Anti-trust Policy, 13890, 13892.

80 Buchwald, "Capitol Punishment".

81 Charles R. Geisst, Monopolies in America: Empire Builders and Their Enemies from Jay Gould to Bill Gates (New York, 2000), 278.

82 Klobuchar, Antitrust, 150.

83 Carole Shifrin, "Climate Now Right for Antitrust Revival," Washington Post, 22
} December 1974, E1.

84 Paul Sturm, "The Lull Before the (Antitrust) Storm," Business Week, 15 August 1977, 25; B. Dan Wood and James E. Anderson, "The Politics of U.S. Antitrust Regulation," American Journal of Political Science 37 (1993): 1, 18 (Figures 1, 2), 20.

85 Geisst, Monopolies, 278. 
antitrust front from the Carter Administration." 86 The Antitrust Division's budget and staff levels indeed continued to increase. ${ }^{87}$ And tougher laws were in prospect. Carter declared in 1978 that "there is a great need for reform" of federal antitrust laws as he established a national commission to study possible improvements. ${ }^{88}$ When Carter's national antitrust commission reported in 1979, it recommended amending the first antitrust law, the Sherman Act of the $1890,{ }^{89}$ to introduce a "no fault" approach where violations could occur without proof of culpable conduct. ${ }^{90}$

Given antitrust law's apparent 1970s vigour, why did a counter-revolution occur as the $20^{\text {th }}$ century drew to a close? For New Brandeisians the answer is clear: Ronald Reagan's election as president in 1980 formally ushered in the Chicago School antitrust era. As Lina Khan has argued, "the failure to preserve competitive markets" attributable to "contemporary antitrust enforcement" can be traced back to "the Chicago School intellectual revolution of the 1970s and 1980s, codified into policy by President Reagan."91

This version of events is too simplistic. Non-Chicago School variables evident prior to the Reagan presidency also contributed substantially to the reconfiguration of antitrust that would ensue. Diminished faith in government was one of these. Noted economist F. M. Scherer has indeed argued that a belief that "government is the problem" was a more

\footnotetext{
$86 \quad$ Sturm, "Lull Before".

87 Wood and Anderson, "Politics", 18 (Figures 1, 2), 21.

88 “Carter Starts Antitrust Study,” New York Times, 22 June 1978, D13.

8926 Stat. 209.

90 James H. Wallace Jr., "Another Year of Significant Congressional Initiatives," Antitrust Law Journal 48 (1979): 1519, 1523-24.
}

91 Khan and Vaheesan, "Market Power," 294. See, though, Eisner, Antitrust, 140, 14649, 171-72, 185, 225-26, 231 (maintaining that Chicago school reasoning had taken hold in the Antitrust Division and the FTC in the 1970s). 
important root cause of late $20^{\text {th }}$ century antitrust counter-revolution than Chicago School theorizing. ${ }^{92}$

The 1970s were a dismal decade for government. America's troubles in Vietnam, the Watergate political scandal, chronic federal budget deficits and bungled efforts to control inflation and unemployment all helped to drive anti-government sentiment from 32 percent in 1964 to 50 percent in 1972 and 67 percent in $1980 . .^{93}$ One by-product, as law professor Reuel Schiller highlighted in a 2019 article on airline deregulation, ${ }^{94}$ was that Democratic politicians who might have been expected to favor increased state involvement in the economy advocated at least a partial retreat. Carter acknowledged in his 1978 State of the Union speech that "(g)overnment cannot solve our problems."95 Influential Democratic senator Ted Kennedy said in a 1979 interview “there is no reason we can’t get the government off the back of American industry in the area of economic regulation." $" 96$ Such sentiments yielded a substantial deregulation-oriented reform legacy in the late 1970s, affecting airlines, railways, trucking and natural gas pricing. ${ }^{97}$

Various accounts of the late $20^{\text {th }}$ century antitrust counterrevolution acknowledge anti-regulation sentiment was a contributory factor. ${ }^{98}$ Antitrust, however, initially seemed to

92 F.M. Scherer, "Conservative Economics and Antitrust: A Variety of Influences," in ed. Robert Pitofsky, How the Chicago School Overshot the Mark: The Effect of Conservative Economic Analysis on U.S. Antitrust (New York, 2008), 30, 36.

93 Brian R. Cheffins, The Public Company Transformed (New York: 2018), 137.

94 Reuel Schiller, “The Curious Origins of Airline Deregulation: Economic Deregulation and the American Left," Business History Review 93 (2019): 729.

95 Kim Phillips-Fein, Invisible Hands: The Businessmen's Crusade Against the New Deal (New York: 2009), 198.

96 Larry Kramer, "U.S. Regulators View Corporate Mergers as Big Trouble," Washington Post, January 14, 1979, H8.

97 Cheffins, Public Company, 140.

98 Klobuchar, Antitrust, 148; Sam Peltzman, "The Decline of Antitrust Enforcement," Review of Industrial Organization 19 (2001): 49, 50; Daniel A. Crane, "A Premature 
be a beneficiary of the deregulatory impulse. ${ }^{99}$ As president, Gerald Ford denounced "the dead hand of government" while calling for "an antitrust policy that validates our commitment to competitive markets." 100 Ted Kennedy pressed in the late 1970s for stronger antitrust laws in tandem with deregulation, arguing in so doing for the abolition of antitrust immunities permitting anticompetitive activity in heavily regulated industries. ${ }^{101}$ Howard Metzenbaum, a Democrat senator who was a proponent of vigorous antitrust enforcement, suggested in a 1987 speech "If you are for free enterprise, then you must be for antitrust. You just can't be for one and against the other."102

Despite Metzenbaum's protestations, in the 1980s antipathy toward government regulation was a catalyst for the recasting of antitrust for which the Reagan administration is credited (or blamed). The Economist drew attention to the pivot in a 1981 article entitled "Trustbusters Busted", saying that U.S. antitrust statutes "supposed to underwrite competition have perversely become confused by conservatives with government regulation."103 The same year the Washington Post indicated that politicians who thought deregulation should be accompanied by a tough antitrust policy were "starting to express their fears" that antitrust was in retreat as compared to "(w)ay back in 1979."104 The Post's take was different: "(t)he

Postmortem on the Chicago School of Antitrust," Business History Review 93 (2019): 759, 766.

99 Eisner, Antitrust, 145.

100 Louis M. Kohlmeier, "Ford, The Shy Trustbuster," Boston Globe, 9 November 1975,

D1.

101 Kramer, "U.S. Regulators".

102 Howard M. Metzenbaum, “Address,” Antitrust Law Journal 56 (1987): 387, 387.

103 Economist, 18 April 1981, 17.

104 Merrill Brown, “Antitrust: More Boom Than Bust," Washington Post, 23 August 1981, G1. 
hullabaloo...should come as no surprise since candidate Reagan...criticized big antitrust cases and big government in the same breath." 105

The Reagan campaign antitrust mentality was sustained during his presidency. As a senior FTC official explained in 1999, “A major part of that administration's economic program was to reduce government regulation. Antitrust enforcement was perceived as being overly intrusive, out of control, and highly regulatory." 106 Reagan trustbusters tended to assume that "traditional antitrust law" - antitrust as enforced during the mid- $20^{\text {th }}$ century "golden age" -- imposed substantial efficiency costs akin to conventional governmental regulation. ${ }^{107}$ Charles Rule, head of the Antitrust Division during the final years of the Reagan administration, referred, for instance, to pre-Reagan antitrust as "know-nothing, attack-everything." ${ }^{108}$ Rule said that, in contrast, the Reagan Antitrust Division was "exceedingly careful to ensure that we prosecute only conduct that is unambiguously anticompetitive and clearly illegal", primarily horizontal practices such as such as pricefixing, bid-rigging and market allocation among competitors. ${ }^{109}$

\section{Foreign Competition}

For Reagan trustbusters such as Charles Rule an "attack-everything" antitrust policy was misguided partly because of potential chilling of "some legitimate, efficient business

$105 \quad$ Ibid.

106 David A. Balto, "Antitrust Enforcement in the Clinton Administration," Cornell Journal of Law and Public Policy 9 (1999): 61, 62.

107 Peter C. Carstensen, "How to Assess the Impact of Antitrust on the American Economy: Examining History or Theorizing?," Iowa Law Review 74 (1989): 1175, 1175-76; see also Lawrence A. Sullivan and Wolfgang Fikentscher, "On the Growth of the Antitrust Idea," Berkeley Journal of International Law 16 (1998): 197, 207.

108 Charles F. Rule, "Setting the Record Straight: The Present is Prologue, Remarks for the 22nd New England Antitrust Conference," 28 October 1988, 11, https://www.justice.gov/atr/speech/setting-record-straight-present-prologue.

109 "60 Minutes with Charles F. Rule -- Assistant Attorney General, Antitrust Division," Antitrust Law Journal 57 (1988): 257, 259, 261. 
practices." 110 When Rule made this point he had in mind a factor that did as much, if not more, to reshape late $20^{\text {th }}$ century antitrust policy than misgivings concerning regulation. This was foreign competition, which, according to Rule, had revealed " $(\mathrm{t})$ he price society had to pay for misguided, at times silly, antitrust policy."111

In 1991, the Economist focused on foreign competition to explain why America's trustbusters had become "timid":

“America's economy is more open today, exposing many big firms to foreign competition. This does not make it impossible for a domestic market to be dominated and then abused, but it is far less likely to happen. If General Motors, Ford and Chrysler were foolish enough to conspire to fix prices, they would quickly lose market share to Toyota, Volkswagen and Hyundai, at home as well as abroad."112

The rise of foreign competition dovetailed with the intellectual trends in operation to reshape thinking about antitrust. As law professor Daniel Crane has said "The Chicago School arose at a time when foreign competition was flooding the U.S. market as never before. Its generally laissez faire policy recommendations for antitrust resonated with realities that many markets were becoming intensely more competitive as a result of foreign entry."113

Foreign competition should make an industry more difficult to monopolize. ${ }^{114}$ As the 1960s got underway, however, approximately 95 percent of steel, automobiles, televisions,

\footnotetext{
$110 \quad$ Ibid., 269.

111 Rule, "Setting the Record," 10-11.

112 “America’s Timid Trustbusters,” Economist, April 27, 1991, 16.

113 Daniel A. Crane, “All I Really Need to Know about Antitrust I Learned in 1912," Iowa Law Review 100 (2015): 2025, 2037.

$114 \quad$ Ning Gao, Ni Peng and Norman Strong, "What Determines Horizontal Merger Antitrust Case Selection?," Journal of Corporate Finance 46 (2017): 51, 52.
} 
radios and other consumer products Americans bought were domestically sourced. ${ }^{115}$ Foreign competition thus seemed an unlikely check on the market power of leading mid-20 ${ }^{\text {th }}$ century American firms. ${ }^{116}$ Perceptions would soon change.

The percentage of goods that Americans used that were imported increased from $8 \%$ in 1969 to $21.2 \%$ in $1979 .{ }^{117}$ By the end of the 1970 s, over $70 \%$ of goods produced in the United States were actively competing with foreign-made goods. ${ }^{118}$ As the 1980s got underway, foreign competition had sideswiped various major industries, including apparel, automobiles, footwear, shipbuilding, steel and televisions. ${ }^{119}$ Concerns were growing, moreover, that American business was stumbling in response to the challenge foreign firms were posing. The Washington Post told readers in 1978 that "From boardroom to research lab, there is a deepening sense that something has happened to the once unchallengeable Yankee ingenuity." 120 In 1980, NBC broadcast an hour-long documentary "If Japan Can Do It, Why Can't We?" which, according to Fortune, "brutally demonstrated the poor quality of U.S. products and processes" 121 and "was one of the great managerial fashion statements of all time." 122

115 Robert Reich, Supercapitalism: The Transformation of Business, Democracy, and Everyday Life (New York, 2007), 43.

116 Paul A. London, The Competition Solution: The Bipartisan Secret behind American Prosperity (Washington D.C., 2005), 44.

117 Ira C. Magaziner and Robert R. Reich, Minding America's Business: The Decline and Rise of the American Economy (New York, 1982), 32.

118 Ibid.; Robert Reich, "The Next American Frontier," Atlantic Monthly, March 1983, 44.

119 Magaziner and Reich, Minding, 203.

120 Bradley Graham, "Something's Happened to Yankee Ingenuity," Washington Post, 3 September 1978, G1.

121 Geoffrey Colvin, “The Ultimate Manager,” Fortune, 22 November 1999, 185.

122 Geoffrey Colvin, “A Concise History of Management Hooey,” Fortune, 28 June, 2004, 166. 
Doubts about antitrust grew in tandem with concerns about foreign competition. A Washington Post columnist argued in 1978 that "the American fear of concentrated power" that underpinned antitrust law seemed "outmoded in today's world" and indicated "What is called for is a new policy that reflects the reality of a U.S. market open to foreign competition." 123 Time, in a 1979 article discussing a major conference on antitrust the magazine had organized, posed the question "Is the function of antitrust to enhance economic efficiency or to ensure the dispersal of economic power into many hands?"124 Its answer: "At a time when the U.S. is struggling to curb inflation, create jobs and sharpen its competitiveness in world markets, the purpose of antitrust policy should be to enhance efficiency."125

Again, despite the foreign dimension, antitrust enforcement in the 1970s was comparatively robust. Time acknowledged the point in its 1979 article, saying "the American Captain of Industry" was "under fresh attack from trustbusters in the Justice Department, the Federal Trade Commission and the Congress." ${ }^{126}$ In contrast, foreign competition clearly affected the mindset of Reagan trustbusters. When J. Paul McGrath took over as head of the Antitrust Division in 1983 he acknowledged "there has been a rather broad shift in thinking about antitrust law" due largely to "an interest in looking at things in terms of economic reality." 127 He emphasized in making this point the need for the United States to remain competitive in a fast-changing global marketplace. ${ }^{128}$ In 1986, Commerce Secretary

123 Marshall I. Goldman and Louis T. Wells Jr., "Save the Business Baronies," Washington Post, 17 September 1978, B1.

124 "New Thrust In Antitrust," Time, 21 May 1979, 62.

125 Ibid.

126 Ibid.

127 Isikoff and Brown, "Baxter's Reign".

Ibid. 
Malcolm Baldrige defended a proposal to relax antitrust restrictions on mergers on the basis that "We are living in an era of intense worldwide competition, and we think American companies should merge if it is going to increase their competitiveness."129

As McGrath's reference to a "broad shift in thinking" implied, foreign competitiondriven antitrust skepticism extended well beyond the Reagan administration in the 1980s. Economists Walter Adams and James Brock wrote in 1986 "American antitrust is under renewed fire. Cast as an economic anachronism in the 'new' age of global competition, it is attacked by critics all along the political spectrum-left and right, liberal and conservative, neoliberal and neoconservative." ${ }^{130}$ Business Week, in making the case that it would not make much difference to antitrust policy if the Democrats or the Republicans won the White House in 1988, struck the same chord, saying "The Reaganites have won the battle. Even many Democrats, concerned about America's ability to compete internationally with Japan Inc., are having second thoughts about the restrictive merger policies they espoused in the 1970s."131 For instance, Nicholas deB. Katzenbach, Attorney General under Lyndon Johnson in the mid-1960s, said in 1981 "The whole time I was down in Washington, people there wanted me to go after General Motors. Wouldn't that look ridiculous today?"'132 Hence, the view was widely shared in the 1980s that due to the potency of foreign competition, antitrust changes the Reagan administration made were appropriately "geared for the times."133

129 John Greenwald and Gisela Bolte, "Plans to Make Mergers Easier," Time, 27 January $1986,38$.

130 Walter Adams and James W. Brock, "The New Learning and the Euthanasia of Antitrust," California Law Review 74 (1986): 1515, 1516.

131 Paula Dwyer, “The Reagan Revolution in Antitrust Won't Fade Away,” Business Week, 18 April 1988, 29.

132 Steve Lohr, “Antitrust: Big Business Breathes Easier,” New York Times, 15 February 1981, F1.

133 Ernest Gellhorn, “An Antitrust Policy Geared for the Times," Washington Post, 26 August 1987, A23. 


\section{Conclusion}

The antitrust counter-revolution associated with the Chicago School and the Reagan administration evolved into "the relative stability of (an) antitrust consensus", ${ }^{134}$ a consensus the New Brandeisians are now seeking to disrupt. In so doing, the New Brandeisians have invoked history, maintaining a reversal of the Chicago School's corruption of a mid-20 $0^{\text {th }}$ century golden age of antitrust is essential. Whatever the merits of the case in favor of antitrust reform, the historical account underpinning calls for change is partial at best and misleading at worst. Mid- $20^{\text {th }}$ century antitrust was not as vigorous as the New Brandeisians imply and the Chicago School was hardly working with a blank slate. During the 1970s and 1980s, doubts mounted about the efficacy of regulation - including antitrust - absent Chicago School theorizing. With foreign competitors gaining ground, an interventionist antitrust policy increasingly seemed to be a luxury the United States could no longer afford. ${ }^{135}$ Perhaps turning the antitrust page would be beneficial now. Regardless, the history that advocates of reform have been putting forward to advance their case should not be accepted at face value.

134 Lina M. Khan, "The End of Antitrust History Revisited," Harvard Law Review 133 (2020): $1655,1656$.

135 Thomas E. Kauper, "Influence of Conservative Economic Analysis on the Development of the Law of Antitrust," in ed. Robert Pitofsky, How the Chicago, 40, 43. 